\title{
Silicon 低減型高強度溶融亜鉛めっき鋼板の開発
}

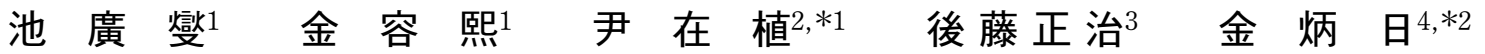 \\ 1現代ハイスコ \\ 2韓国基礎科学支援研究院順天センター \\ 3 秋田大学工学資源学部材料工学科 \\ 4 順天大学材料金属工学科
}

J. Japan Inst. Metals, Vol. 73, No. 10 (2009), pp. 816-821

(C) 2009 The Japan Institute of Metals

\section{Development of Low Silicon Galvannealed TRIP Steel with High Strength}

\author{
Kwang Sub Chi ${ }^{1}$, Yong Hee Kim¹ㄹ Jae Sik Yoon ${ }^{2, * 1}$, Shoji Goto ${ }^{3}$ and Byung Il Kim²,*2 \\ ${ }^{1}$ Hyundai Hysco, Dangjin Works 313, Donggok-ri, Songsan-Myeon, Dangjin-gun, Chungnam 343-831, Korea \\ ${ }^{2}$ Korea Basic Science Institute Suncheon Center, Suncheon 540-742, Korea \\ ${ }^{3}$ Department of Materials Science and Engineering, Faculty of Engineering and Resource Science, Akita University, Akita 010-8502 \\ ${ }^{4}$ Department of Material Science and Metallurgical Engineering Suncheon National University, Suncheon 540-742, Korea
}

\begin{abstract}
Hot-dip galvannealed sheet (GA) were developed from the automotive industry. It has high strength of $590 \mathrm{MPa}$ grade in tensile strength. However, in order succeeds from automobile industry, the microstructure and galvannealing behavior of galvannealed TRIP steel sheets must be strictly controlled. The metal where the silicon content is high has problems with weld-ability, zinc coating and reduction of retained austenite volume fraction after galvannealing process. The main purpose of this study is to solve the problem as indicated above.
\end{abstract}

(Received February 12, 2009; Accepted July 2, 2009)

Keywords: trip steel, microstructure, retained austenite, high strength

\section{1. 序論}

最近自動車の燃費と排気ガスに対する規制が強化されるこ とになり，自動車軽量化のための技術開発がいっそう加速化 している. 特に自動車車体の軽量化, 防錆性と材料の選択的 な側面から延伸性重視型の代表鋼である残留オーステナイト 変態誘起塑性鋼 (Trip Steel) を母材とする高張力合金化溶融 亜鉛めっき鋼板の開発が進んでいる．変態誘起塑性鋼板は高 温のオーステナイト領域でオーステナイト組織を生成させた 後, $400^{\circ} \mathrm{C}$ 程度の温度でベイナイト変態熱処理を行うと, 炭 素が未変態オーステナイト相に濃化されて, 常温でも安定し た残留オーステナイト組織が得られるようにした鋼板であ る1-3).このように常温で残留するオーステナイト相は, 加 工時に硬質のマルテンサイト組織に変態しながら材料の塑性 変形を大きくして強度と成形性を同時に満足させる役割をす る4-6). しかし，この素材開発で問題となるのはフェライ ト, ベイナイト変態の進行によって未変態オーステナイト相 に濃化された C をセメンタイトとして析出させないことが 重要であり，これを抑制するために添加されている Si が母 材鋼板と溶融亜鉛の湿潤性 (Wettability) を劣化させ, 非め

${ }^{* 1}$ Corresponding author, E-mail: jaesiky@kbsi.re.kr

*2 Co-corresponding author, E-mail: kbi@sunchon.ac.kr
つきを起こすと同時に合金化を遅らせる作用をするのであ る. 必要な合金化を果すために合金化温度を高めると, セメ ンタイトの析出が促進されて Trip 現象に必要なオーステナ イト相を十分に残留させることが難しくなる7-9). 従って, 連続焼鈍後, 溶融めっきおよび合金化処理が連続的に行なわ れるCGL (Continuous galvanizing line)の場合, 合金化処理 条件が制限されることになり, 製造上の難しさがある. 本研 究では実際 $\mathrm{Si}$ 含量を制限して $\mathrm{Si}$ 低減型 $590 \mathrm{MPa}$ 級の高強 度鋼を開発するために, 焼鈍熱処理および冷却するなどの合 金化温度条件を最適化して引張強度 $590 \mathrm{MPa}$ 以上および延 伸率 $28 \%$ 以上の特性を持った変態誘起塑性鋼の溶融亜鉛め っき鋼板製造特性を調査することを目的とする.

\section{2. 実 験 方 法}

\section{1 素材準備}

本研究で使用した試料の基本組成を Table 1 に示した. 焼 鈍熱処理および合金化溶融めっきに使用する素材の準備とし て真空誘導炉で溶解して $35 \mathrm{~mm}$ 厚に研削した後, 均質化の ために再加熱して実験用圧延機で熱間圧延を行って $4 \mathrm{~mm}$ 厚 さの熱延板を得た. $1250^{\circ} \mathrm{C} て ゙ 2$ 時間再加熱処理を行った 後, 仕上げの圧延温度を $910^{\circ} \mathrm{C}$ 以上に維持し, 熱間圧延が 終わった素材は $650^{\circ} \mathrm{C} て ゙ 30$ 分間保持した後, 炉冷して巻取 
Table 1 Chemical composition of specimen.

\begin{tabular}{ccccccc} 
& & & & & \multicolumn{2}{c}{ (mass\%) } \\
Element & $\mathrm{C}$ & $\mathrm{Si}$ & $\mathrm{Mn}$ & $\mathrm{Al}$ & $\mathrm{Cu}$ & $\mathrm{Co}$ \\
\hline Content & 0.15 & 0.30 & 1.50 & 1.00 & 0.50 & 0.35 \\
\hline
\end{tabular}

Table 2 Cold rolling conditions of specimen.

\begin{tabular}{ccccc}
\hline Conditions & C.R.1 & C.R.2 & C.R.3 & C.R.4 \\
\hline Thickness $(\mathrm{mm})$ & 2.4 & 1.9 & 1.5 & 1.0 \\
\hline Reduction $(\%)$ & 40 & 53 & 63 & 75 \\
\hline
\end{tabular}

条件を再現した。熱間圧延された試片は塩酸(10\%)で酸洗 浄して表面の酸化スケールを除去した後, Table 2 に示すよ うに 40〜 75\%まで段階別に連続冷間圧延を行い, さまざま な圧下率の試片を製作してその特性を評価した。

\section{2 連続焼鈍熱処理条件}

連続焼鈍熱処理実験では高速熱処理シミュレーター (CCT-AV, Shinkurico 社)を使って連続焼鈍熱処理実験を実 施し，Fig. 1 に示している焼鈍温度 $(\mathrm{SS})$ と合金化温度 (GA) を一緒に変化させてその影響を調べた，CGL連続焼鈍 Cycle を勘案し, 各区間の固定温度は先に予備実験を実施し て決めて抢り，良好な機械的特性が得られる温度が焼鈍温度 (SS) $820^{\circ} \mathrm{C}$, 急冷開始温度 $(\mathrm{RCS}) 670^{\circ} \mathrm{C}$, 恒温変態処理温度 (LTH) $465^{\circ} \mathrm{C}$ という事実を確認した後, それらの温度を基 準にして Table 3 に示すように焼鈍温度 $(\mathrm{SS})$ 抢よび合金化 温度 $(\mathrm{GA})$ を同時に变化させて機械的特性と微細組織の関係 について調べた.

\section{3 溶融めっきおよび合金化熱処理の条件}

連続焼鈍熱処理後, 溶融めっきおよび合金化熱処理は日本 の Shinkurico 社で製作された垂直型溶融めっきのシミュ レーターで連続的に実施した．この時のめっき条件は Table 4 に示すとおりである. 合金化熱処理条件では Table 3 で概 略的に示したように合金化熱処理温度を 460 から $560^{\circ} \mathrm{C}$ ま で $20^{\circ} \mathrm{C}$ 間隔で変化させてその特性を調査した.

\section{4 機械的性質および微細組織の特性評価}

熱処理した試片は JIS5 号試験片の形状に加工した後, 万 能引張試験機 $(Z 100, Z$ wick )を使って機械的性質を調べた. また，素材の微細組織分析のために光学顕微鏡と Electron Backscatter Diffraction(EBSD，OIM 4.5，TSL)を備えた Field-Emission Gun Scanning Electron Microscope(FEGSEM, JSM-7000F, JEOL) 分析装置を使用した。機械的性質 と残留オーステナイトの関係を明らかにするために X-ray Diffraction(XRD, RINT 2200, Rigaku)を使って残留オース テナイト分率を分析した．XRDのターゲットにはMoを用 い，スキャン速度は $1^{\circ} \mathrm{Co} / \mathrm{sec}$ で分析した. 残留オーステナ イト分率は XRD ピークの積分強度を計算した後に Miller ${ }^{10)}$ が提示した式(1)を使って計算した。 また，各条件で試片の 断面を $\mathrm{Na}_{2} \mathrm{~S}_{2} \mathrm{O}_{5} 7 \%$ 水溶液でエッチングし，微細組織を分析 した.
Temperature $\left({ }^{\circ} \mathrm{C}\right)$

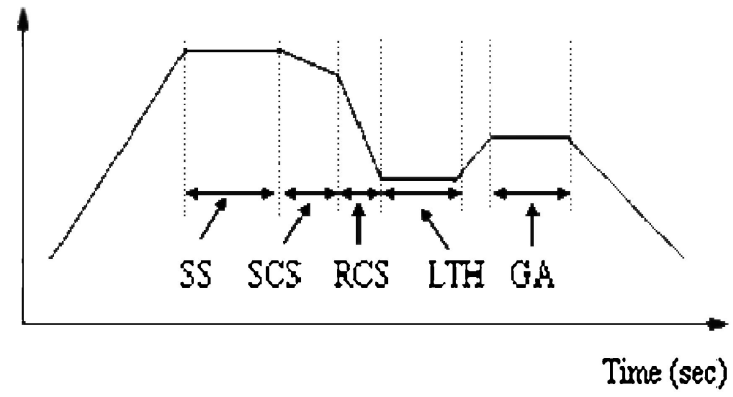

Fig. 1. Schematic sketch of heat treatment cycles.

Table 3 Experimental conditions of specimen.

\begin{tabular}{cccc}
\hline $\mathrm{SS}\left({ }^{\circ} \mathrm{C}\right)$ & $\mathrm{RCS}\left({ }^{\circ} \mathrm{C}\right)$ & $\mathrm{LTH}\left({ }^{\circ} \mathrm{C}\right)$ & $\mathrm{GA}\left({ }^{\circ} \mathrm{C}\right)$ \\
\hline 760 & & & 460 \\
780 & & & 480 \\
800 & & 465 & 500 \\
820 & 670 & & 520 \\
840 & & & 540 \\
860 & & $54 \mathrm{~s}$ & 560 \\
\hline $114 \mathrm{~s}$ & $11 \mathrm{~s}$ & & $25 \mathrm{~s}$ \\
\hline
\end{tabular}

Table 4 Variables of hot-dip galvanizing experiments.

\begin{tabular}{lc}
\hline \multicolumn{1}{c}{ Variables } & Experimental conditions \\
\hline Galvanizing temp $\left({ }^{\circ} \mathrm{C}\right)$ & 465 \\
\hline Coating weight $\left(\mathrm{g} / \mathrm{m}^{2}\right)$ & 60 \\
\hline Bath composition $($ mass $\%)$ & $\mathrm{Al}: 0.130, \mathrm{Fe}: 0.004, \mathrm{~Pb}: 0.0008$ \\
\hline
\end{tabular}

$$
\mathrm{V} \gamma(\%)=100 \times(1.4 I \gamma) /(I \alpha+1.4 I \gamma)
$$

$V \gamma:$ オーステナイトの体積分率

$I \gamma \quad:$ オーステナイト相の積分強度

$I \alpha$ : フェライト相の積分強度

\section{5 合金層の特性評価}

合金層内の $\mathrm{Fe}$ 含量は，塩酸と水を $1: 3$ で混合した後， 腐食抑制剂としてへキサミンを 1 ～滴添加した溶液で合金 層を溶解して Inductively Coupled Plasma (ICP)で分析し た. 合金化熱処理条件によるめっき試験片の表面, 断面組織 およびめっき層内の $\mathrm{Fe}-\mathrm{Zn}$ 合金相である $\zeta, \delta 1$ および $\Gamma 1$ 相 はめっき層をエッチングした後, SEM で分析した，合金層 の相変化観察打よび成分分析には Atomic Emission Spectrometer (AES)を使用した.

\section{3. 実験結果および考察}

\subsection{Hot Coil の微細組織}

冷間圧延前のホットコイルの縦断面で観察された微細組織 を Fig. 2 に示す．結晶粒の大きさは約 $11 \mu \mathrm{m}$ であり，比較 的に高い巻取温度と炭素含量によって結晶粒界には粗大な炭 化物が析出していることが確認できる. 結晶粒径と相分率が 全体的に均一な分布を示しており, 従来報告されているとお り $\mathrm{Si}$ はフェライトの析出を促進させるが，本実験のように 

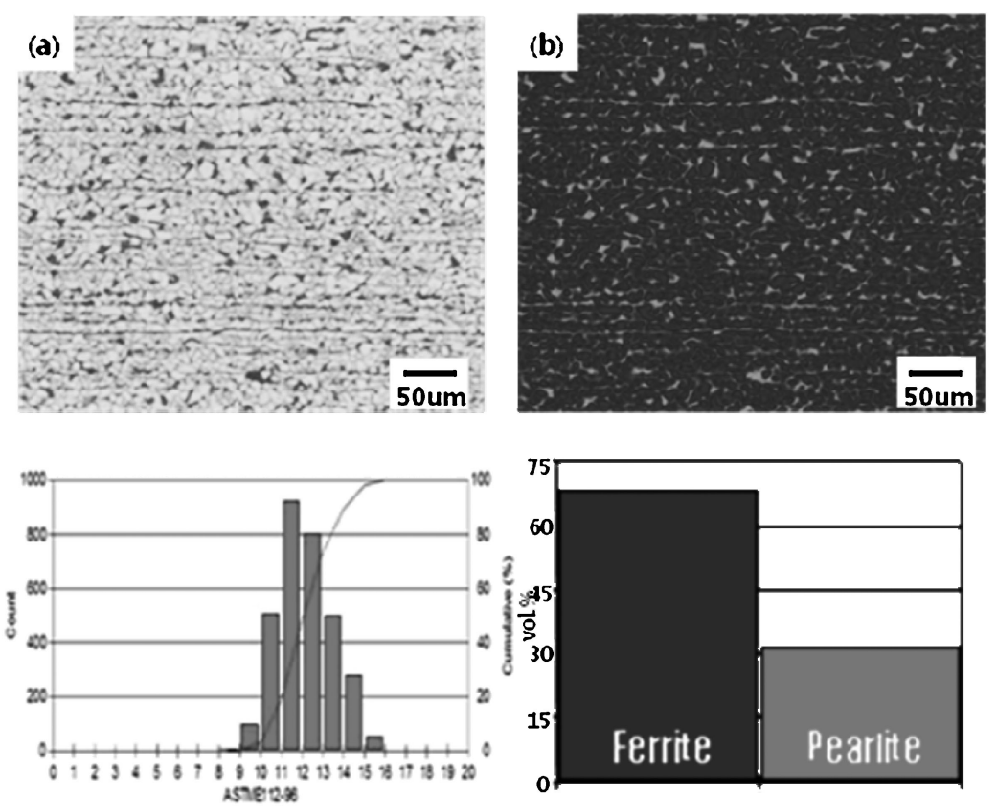

Fig. 2. Microstructure and phase volume fraction of hot coil (a) Optical microstructure and grain size and (b) Phase volume fraction of ferrite and pearlite.

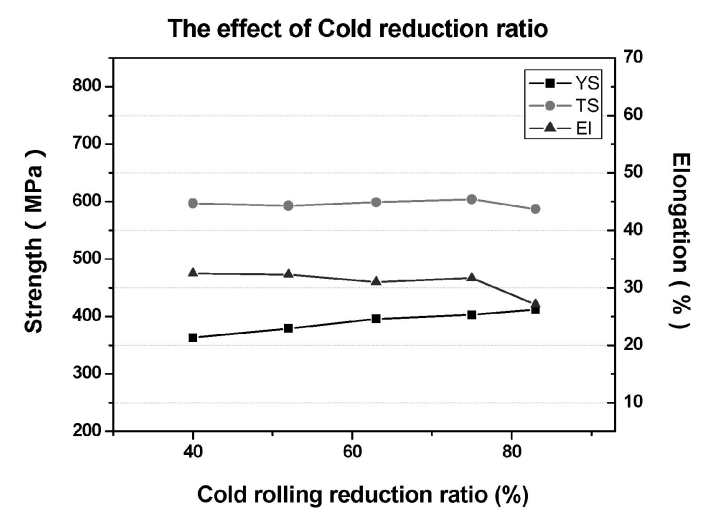

Fig. 3. Effects of cold rolling reduction ratio on the mechanical properties of TRIP-aided steel.

比較的低い $\mathrm{Si}$ 含量でもフェライトが $68 \%$, パーライトが $32 \%$ と安定した相分率が観察された.

\section{2 冷間圧下率の影響}

Fig. 3 は冷間圧下率変化による变態誘起塑性鋼の機械的特 性を示す。本研究では冷間圧下率が 40～75\%のときに安定 した物性值確保が可能であり, 75\%を超えた場合は引張強 度と延伸率が低下することがわかる。

冷間圧下率が増加すればするほど素材の結晶粒径が減少し， Fig. 4 に示すようにすべての泠間圧下率条件抢よび熱処理条 件で合金元素の偏析に起因したバンド構造が観察された。な お，結晶粒の大きさは約 $10 \mu \mathrm{m}$ 程度であった。

\section{3 焼鈍温度の影響}

連続焼鈍工程の熱処理温度変化による変態誘起塑性鋼の機 械的特性変化を観察するために各温度を変化させて熱処理試 験を実施し, 試料の機械的特性を分析した結果を Fig. 5 に 示した。まず，焼鈍温度の影響を調べるために急冷開始温度
を $670^{\circ} \mathrm{C}$, 恒温変態処理温度を $465^{\circ} \mathrm{C}$ に固定した後, 焼鈍温 度を $760^{\circ} \mathrm{C}$ から $860^{\circ} \mathrm{C}$ まで $20^{\circ} \mathrm{C}$ の間隔に变化させた. 降伏 強度の場合はほぼ一定の值を示しているが， $820^{\circ} \mathrm{C}$ 以上では 次第に減少する様子をみせている. 引張強度の場合は $840^{\circ} \mathrm{C}$ まで増加しているが，それ以上の温度ではやや減少した值を 示した. 延伸率の場合も降伏強度と似た傾向を示したが, $820^{\circ} \mathrm{C}$ までは増加していたもののそれ以上ではわずかに減少 する様子を示した。これは $820^{\circ} \mathrm{C}$ 以上の温度でオーステナ イト体積率が大きくなり, これによってオーステナイトの炭 素濃度が減少するためであると考えられる11)。

\section{4 合金化温度の影響および微細組織}

亜鉛めっきをした後, 合金化温度を $460^{\circ} \mathrm{C}$ から $560^{\circ} \mathrm{C}$ ま で $20^{\circ} \mathrm{C}$ 間隔に変化させ, $500^{\circ} \mathrm{C}$ から $540^{\circ} \mathrm{C}$ までの機械的特 性変化を Fig. 6 に示した。 また, Table 5 には合金化温度別 の残留オーステナイト分率を表示した．これらのことより合 金化温度が上昇すると残留オーステナイト分率が減少し, こ れによって延伸率は急激に減少することがわかる。これは合 金化温度が上がれば上がるほど，オーステナイトがベイナイ トや炭化物に変態しすぎるためであり, したがって素材の機 械的特性值を満足させるためにはその温度を $520^{\circ} \mathrm{C}$ 以下に 維持しなければならないことがわかる.

Fig. 7 は合金化熱処理温度によって存在する亜鉛めっき層 内の相の分布を示したものである. 合金化温度が上昇するこ とによって代表的な亜鉛相のイータ $(\eta ; Z n)$ 相が急激に減少 し, 亜鉛層に $\mathrm{Fe}$ が結合されたデルタ $(\delta 1 ; \mathrm{Fe} Z \mathrm{n} 7)$ 相が発達 するようになる．また，この時表面層に形成されたツェータ ( ; FeZn13) 相も徐々に減少するようになる. 一般に自動車 用 $\mathrm{GA}$ 鋼板では合金化度 $(\mathrm{Fe} \%)$ は 8 13\%の範囲内に管理 されているが，このように $\mathrm{Fe} \%$ を制限する理由は $8 \%$ 以下 になると溶接性が悪くなり，13\%以上になるとめっき層と 素地界面に硬い特性を持つガンマ $(\Gamma 1 ; \mathrm{Fe} 2 \mathrm{Zn} 21)$ 相が大量 

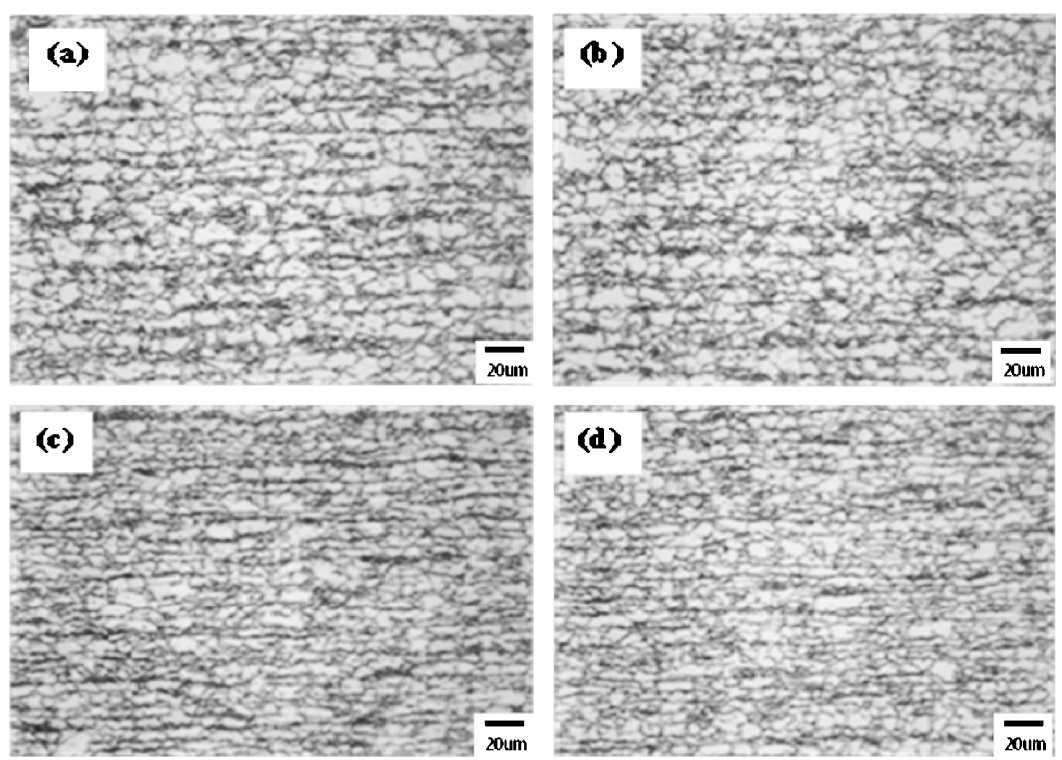

Fig. 4. Effect of cold rolling reduction ratio on microstructure of TRIP-aided steel (a) $40 \%$, (b) $53 \%$, (c) $63 \%$ and (d) $75 \%$

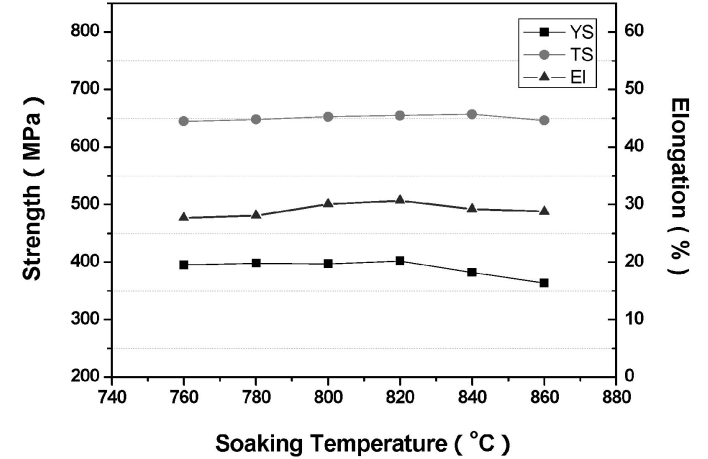

Fig. 5. Effect of soaking temperature on the mechanical properties after galvannealing at $520^{\circ} \mathrm{C}$ for $25 \mathrm{~s}$.

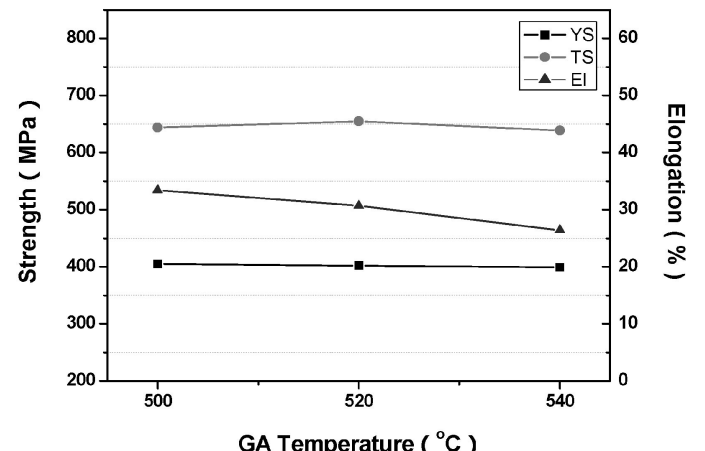

Fig. 6. Effect of galvannealing temperature on the mechanical properties after soaking at $820^{\circ} \mathrm{C}$ for $114 \mathrm{~s}$.

に生成され，加工時に粉末化 (Powdering) 現象が激しく発生

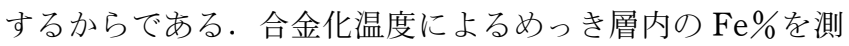
定した結果， $500^{\circ} \mathrm{C}$ の場合 $8.6 \% ， 520^{\circ} \mathrm{C}$ の場合 $11.6 \%$ と安 定した合金化度 $(\mathrm{Fe} \%)$ を示したが，合金化温度が $480^{\circ} \mathrm{C}$ 末 満の場合は $5 \%$ 以下， $540^{\circ} \mathrm{C}$ を超える場合は $13 \%$ 以上となり 管理範囲を外れた。

Fig. $8(\mathrm{a}),(\mathrm{b})$ は $520^{\circ} \mathrm{C} て ゙ 25$ 秒間合金化処理を行った時に
Table 5 Volume fraction of retained austenite for specimen.

\begin{tabular}{cccc}
\hline $\mathrm{SS}\left({ }^{\circ} \mathrm{C}\right)$ & $\mathrm{GA}\left({ }^{\circ} \mathrm{C}\right)$ & $\mathrm{El}(\%)$ & $\gamma$ vol $(\%)$ \\
\hline 820 & 520 & 30.3 & 2.1 \\
820 & 460 & 33.6 & 7.3 \\
\hline
\end{tabular}

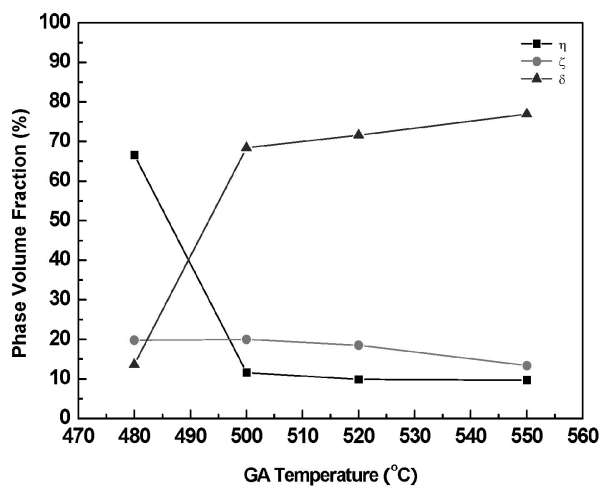

Fig. 7. Phase volume fraction in zinc coated layer according to the galvannealing temperature.

めっき層の表面および断面組織を観察したものである．Fig. $8(\mathrm{a})$ から表面まで完全に合金化されており，主に $\delta 1$ 相で構 成されていることを観測することができ，また Fig. 8(b)か らパウダリング性に一番脆弱な $\Gamma 1$ 相が素地界面に薄く形成 されていることを確認することができた。一般的に $\Gamma 1$ 相は $0.5 \mu \mathrm{m}$ 以下で管理しなければならないとされている。また， Table 6 に各相の特性を示す。

Fig. 9 はめっき層断面の元素分布を測定した結果である. 合金化熱処理後の $\mathrm{Fe}-\mathrm{Zn}$ 合金層厚さは約 $7 \mu \mathrm{m}$ に形成され ていることが観察されて抢り, AES 分析の結果, 合金層表 面から $3 \mu \mathrm{m}$ までは Fe と $\mathrm{Zn}$ 組成がほとんど均一であった が，母材との境界面に近づくと組成の差が明らかに大きくな ることがわかる。 


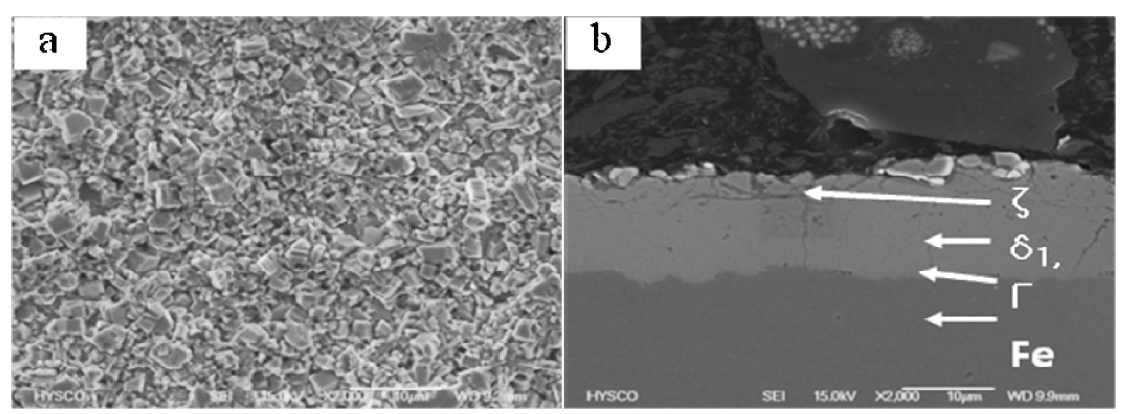

Fig. 8. Surface and cross sectional view of coating layer after galvannealing at $520^{\circ} \mathrm{C}$ for $25 \mathrm{~s}$ (a) Surface appearance and (b) Cross sectional view, $\Gamma$ phase $\left(\mathrm{Fe}_{5} Z_{21}\right), \delta_{1}$ phase $\left(\mathrm{FeZn}_{7}\right)$ and $\zeta$ phase $\left(\mathrm{FeZn}_{13}\right)$.

Table 6 Physical properties of $\mathrm{Fe}-\mathrm{Zn}$ intermetallic compounds.

\begin{tabular}{|c|c|c|c|c|c|}
\hline \multicolumn{2}{|c|}{ Class. } & $\Gamma$ & $\delta_{1}$ & $\zeta$ & $\eta$ \\
\hline \multicolumn{2}{|c|}{ Chemical formula } & $\mathrm{Fe}_{5} \mathrm{Zn}_{21}$ & $\mathrm{FeZn}_{7}$ & $\mathrm{Fe} Z \mathrm{n}_{13}$ & $\mathrm{Zn}$ \\
\hline \multicolumn{2}{|c|}{ Zn mass\% } & $72 \sim 80$ & $88.6 \sim 93.0$ & $93.8 \sim 94.5$ & 100 \\
\hline \multicolumn{2}{|c|}{ Crystal structure } & $\mathrm{HCP}$ & $\mathrm{HCP}$ & Monoclinic & $\mathrm{HCP}$ \\
\hline \multicolumn{2}{|c|}{ The number of atom per unit cell } & 52 & $550 \pm 8$ & 28 & 2 \\
\hline \multicolumn{2}{|c|}{$\begin{array}{l}\text { Lattice parameter } \\
\qquad(\AA)\end{array}$} & $8.956 \sim 8.9997$ & $\begin{array}{l}a=12.8 \\
c=57.6 \\
c / a=4.5\end{array}$ & $\begin{array}{c}a=13.65 \\
c=7.61 \\
c=5.06 \\
\beta=128^{\circ} 44^{\prime}\end{array}$ & $\begin{array}{c}a=2.66 \\
c=4.9379 \\
c / a=1.8563\end{array}$ \\
\hline \multicolumn{2}{|c|}{ Specific gravity } & 7.36 & 7.25 & 7.18 & 7.14 \\
\hline \multirow{2}{*}{ Hardness } & $\mathrm{H}_{\mathrm{R}} \mathrm{K} 25 \mathrm{~g}$ & - & $458 \sim 463$ & $269 \sim 278$ & $36 \sim 64$ \\
\hline & MHv $5 \mathrm{~g}$ & 421 & 265 & 181 & 45 \\
\hline
\end{tabular}

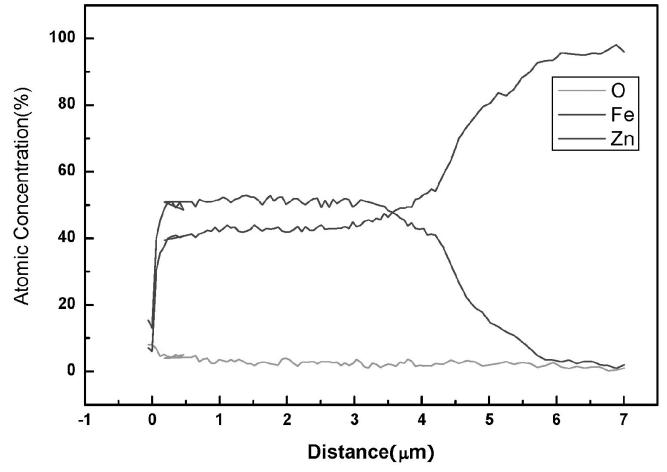

Fig. 9. Phase change observation of galvannealed coating layer.

\section{5 残留オーステナイトの形態および最終微細組織}

常温で存在する残留オーステナイトの形態および微細組織 を観察するために Transmission Electron Microscopy (TEM) と Scanning Electron Microscopy (SEM)を使って分 析を行なった．Tintエッチング液でエッチングする場合, 灰色のフェライト基地相で残留オーステナイト組織は明るい 色に現われ，ベイナイト組織は暗い色に現われる. Fig. 10 は焼鈍温度 $820^{\circ} \mathrm{C}$, 恒温変態処理温度 $465^{\circ} \mathrm{C}$ で熱処理した素 材の微細組織で, 常温で存在する残留オーステナイトの形状 を示したものである. 熱処理温度が $760^{\circ} \mathrm{C}$ 以下の場合, 残 留オーステナイト組織は非常に微細であり, その量も少なく 観察しにくかったが， $800^{\circ} \mathrm{C}$ 以上の温度では量も多くなり安
定的なオーステナイト分率を確保することができた.

Fig. 11(a) は基地フェライトに接している層状のパーライ 卜組織を示しており，合金化の進行過程中に発生したものと 思われる. Fig. 11(b)は微細組織観察相膜状の残留オーステ ナイトが主に基地フェライト多重点に位置し，ラスベイナイ 卜 (細い実線) と接して存在する混合微細組織を示している.

\section{4. 結論}

本研究では $\mathrm{Si}$ 低減型変態誘起塑性鋼を用い, 熱間圧延工 程を経て $650^{\circ} \mathrm{C}$ の温度で巻取した後, $75 \%$ の圧下率で冷間 圧延させた. また, $820^{\circ} \mathrm{C} て ゙$ 再結晶焼鈍熱処理を実施し, 冷 却して $465^{\circ} \mathrm{C}$ の温度で亜鉛めっきを施した後に $520^{\circ} \mathrm{C}$ の温 度で合金化熱処理を行い, 最終冷却をしてその特性を分析し た.その結果，鋼鉄組織中では体積率 $2.1 \%$ の残留オーステ ナイトを含んでおり，めっき層内では合金化度 $(\mathrm{Fe} \%)$ が $11.6 \%$ の安定した值を示し, 引張強度 $604 \mathrm{MPa}$, 延伸率 $30.3 \%$ という優れた物性值を確保することができ, 次のよう な結論を得た。

（1）低い $\mathrm{Si}$ 含量でも相分率はフェライトが $68 \%$ ，パーラ イトが $32 \%$ で安定的に観察された。 また，熱間圧延された コイルの微細組織の結晶粒の大きさは約 $11 \mu \mathrm{m}$ であった.

（2）変態誘起塑性鋼の冷間圧下率が $40 \sim 75 \%$ の場合, 安 定した物性值確保が可能であり, 冷間圧下率が増加すると素 材の再結晶結晶粒径が小さくなった.

（3）焼鈍熱処理温度が上昇すると素材の機械的性質は向上 

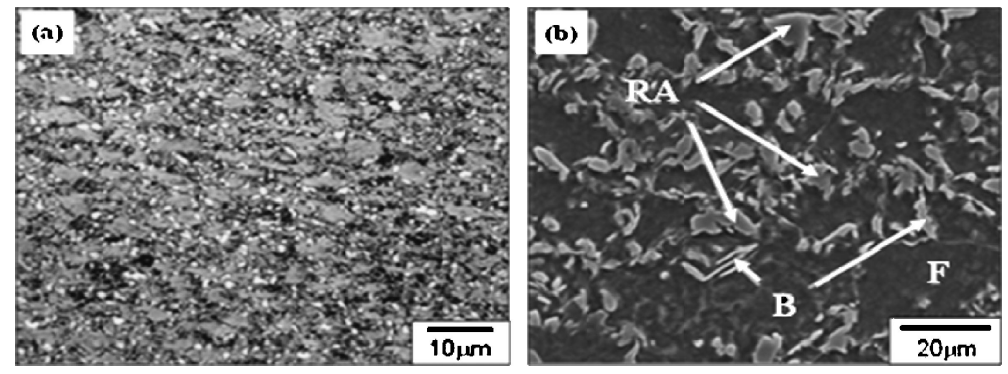

Fig. 10. Scanning electron micrographs of the interfacial layer after soaking at $820^{\circ} \mathrm{C}$ for $114 \mathrm{~s}$ and isothermal heating at $465^{\circ} \mathrm{C}$ for $54 \mathrm{~s}$ (a) Optical microstructure (Tint etched) and (b) Scanning electron microstructure (Nital etched).
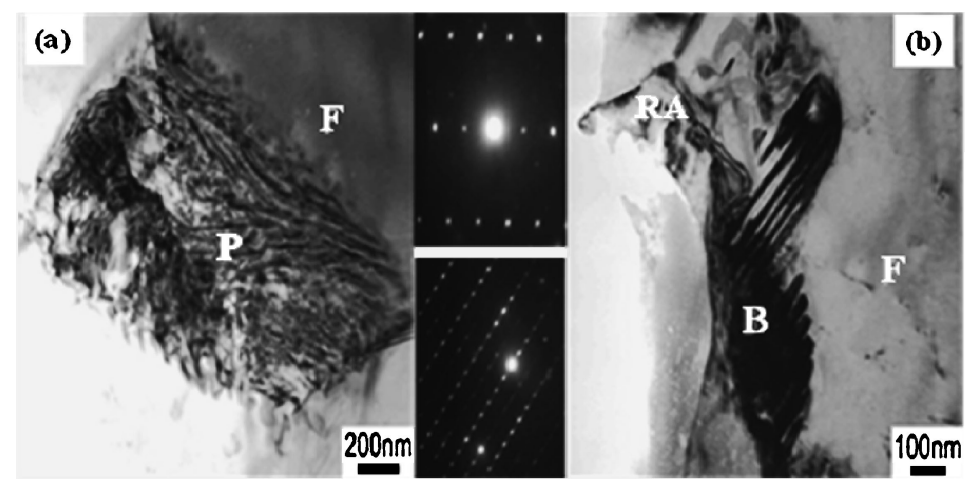

Fig. 11. Transmission election micrographs of Trip-aided steel (a) TEM bright images for pearlite (P) and ferrite (F) phase and (b) TEM bright images for retained austenite (RA), bainite (B) and ferrite (F) phase.

したが， $820^{\circ} \mathrm{C}$ 以上に保持した場合は素材の残留オーステナ イト分率の減少によって機械的性質は劣化する。

(4) 合金化熱処理温度が上がれば上がるほど残留オーステ ナイト分率が減少し，これによって延伸率は急激に減少す る. また，合金化熱処理温度も残留オーステナイト分率を決 定することに重要な役割をする．したがって，合金化熱処理 温度を $520^{\circ} \mathrm{C}$ 以下に維持することが重要である。

(5) 最終微細組織の観察時に残留オーステナイト形状は膜 状で観察されており，主に基地フェライト多重点に位置しな がら，ラスベイナイトと混合した微細組織を示す。
文献

1) F. E Goodwin: Fifth Inter. Conf. on Zinc Coated Steel Sheet. EGGA, Birmingham, 1, (1997).

2) O. Matsumura, Y. Sakuma and H. Takechi: Trans. ISIJ 27 (1987) 570.

3) B. Ehrhardt et al.: AHSSS Prodeedings, (Colorado, 2004) p. 39.

4) X. V. Eynde et al.: Galvetech '04 conf. proc., (2004) p. 361.

5) Y. Sakuma, O. Matsumura and H. Takechi: Metall. Trans. A 2(1991) 489 .

6) I. Tsukatani, T. Kamei, S. Hashimoto and K. Hosomi: Microalloyed HSLA Steels, ASM International, (Chicago, Illinois, 1988) p. 541.

7) J. Mahieu, J. Maki, B. C. De Cooman and S. Claessens: Metall. Mater. Trans. A 33(2002) 2573.

8) M. De Meyer, J. Mahieu and B. C. De Cooman: Mater. Sci. Tech. 18(2002) 1121.

9) S. Traint, A. Pichler, K, Hauzenberger, P. Stiaszny and E. Werner: Inter. Conf. TRIP-Aided High Strength Ferrous Alloys, ed. by B.C. De Cooman, (Ghent, Belgium, 2002) p. 121.

10) R. L. Miller: Trans. ASM 61(1968) 592.

11) S. Hiwatashi et al.: CAMP-ISIJ 5 (1992) 1847. 